University of Nebraska - Lincoln

DigitalCommons@University of Nebraska - Lincoln

Effects of piperidine and piperideine alkaloids from the venom of red imported fire ants, Solenopsis invicta Buren, on Pythium ultimum Trow growth in vitro and the application of piperideine alkaloids to control cucumber damping-off in the greenhouse

Shezeng Li

Hebei Academy of Agricultural and Forestry Sciences

Xixuan Jin

USDA-ARS-MSA, xixuan.jin@ars.usda.gov

Jian Chen

USDA-ARS-MSA, jian.chen@ars.usda.gov

Follow this and additional works at: https://digitalcommons.unl.edu/usdaarsfacpub

$\mathrm{Li}$, Shezeng; Jin, Xixuan; and Chen, Jian, "Effects of piperidine and piperideine alkaloids from the venom of red imported fire ants, Solenopsis invicta Buren, on Pythium ultimum Trow growth in vitro and the application of piperideine alkaloids to control cucumber damping-off in the greenhouse" (2012). Publications from USDA-ARS / UNL Faculty. 1109.

https://digitalcommons.unl.edu/usdaarsfacpub/1109

This Article is brought to you for free and open access by the U.S. Department of Agriculture: Agricultural Research Service, Lincoln, Nebraska at DigitalCommons@University of Nebraska - Lincoln. It has been accepted for inclusion in Publications from USDA-ARS / UNL Faculty by an authorized administrator of DigitalCommons@University of Nebraska - Lincoln. 


\title{
Effects of piperidine and piperideine alkaloids from the venom of red imported fire ants, Solenopsis invicta Buren, on Pythium ultimum Trow growth in vitro and the application of piperideine alkaloids to control cucumber damping-off in the greenhouse
}

\author{
Shezeng Li, ${ }^{a}$ Xixuan Jin ${ }^{b *}$ and Jian Chen ${ }^{b}$
}

\begin{abstract}
BACKGROUND: Pythium ultimum is a plant pathogen that causes significant yield losses on many economically important crops. Chemical treatment has been used for disease control. In searching for alternatives, venom piperidine and piperideine alkaloids from red imported fire ants were tested against $P$. ultimum in vitro, and piperideines were employed to control cucumber damping-off in the greenhouse as drench treatments.
\end{abstract}

RESULTS: Piperidine and piperideine alkaloids of the red imported fire ant significantly inhibited mycelium growth of $P$. ultimum. Piperidine alkaloids were stable at both room and elevated temperatures. The inhibitory activity positively correlated with the concentrations of piperidine alkaloids in the medium, and the $\mathrm{EC}_{50}=17.0 \mu \mathrm{g} \mathrm{ml}^{-1}$. Germination of sporangia of $P$. ultimum was negatively correlated with the concentrations of piperidine alkaloids in the medium, and the $\mathrm{EC}_{50}=12.3 \mu \mathrm{g} \mathrm{ml}^{-1}$. The piperideine alkaloid drenching treatment significantly improved seedling emergence and seedling height of cucumber.

CONCLUSION: This is the first report describing the use of venom alkaloids from the red imported fire ant to inhibit $P$. ultimum in the laboratory and the application of piperideine alkaloids to control damping-off disease caused by $P$. ultimum in the greenhouse. These findings may lead to the development of a new group of fungicides.

(c) 2012 Society of Chemical Industry

Supporting information may be found in the online version of this article.

Keywords: piperidines; piperideines; venom alkaloids; Pythium ultimum; red imported fire ant

\section{INTRODUCTION}

Several Pythium species are ubiquitous soilborne plant pathogens that attack a wide range of economically important host plant species, including forestry and horticultural nursery plants. ${ }^{1}$ Pythium infection causes pre- and post-emergence damping-off or poor growth of mature plants, resulting in significant yield losses. Control measures for reducing damage caused by Pythium spp. usually consist of modifications to cultural practices and application of chemical pesticides. ${ }^{2}$ Seed treatment with chemicals is employed to protect seeds or seedlings from Pythium infection, whereas modifications of cultural practice, such as controlling seed planting depth, are used to promote germination and reduce root infections of seedlings. Drench treatments with chemicals and biologicals have also been used by growers to manage plant diseases caused by Pythium spp. Dichlone, captan and cycloheximide were the first group of fungicides used to control plant diseases caused by Pythium spp.; however, they provided only limited protection. In 1979, metalaxyl was registered in the
United States specifically for the control of Pythium spp. Long-term application of chemical fungicides has resulted in the development of pathogen resistance and failure of disease control. ${ }^{3}$ Chemicals used to control Pythium infections have shown hazardous effects on the environment and humans. It has been documented that captan is not only hazardous to fish but also a mutagenic and carcinogenic agent. ${ }^{4,5}$ Concerns over the hazardous effects of chemical pesticides on the environment and humans have led to

\footnotetext{
Correspondence to: Xixuan Jin, Biological Control of Pests Research Unit, The National Biological Control Laboratory, USDA-ARS-MSA, 59 Lee Road, PO Box 67, Stoneville, MS 38776, USA. E-mail:xixuan.jin@ars.usda.gov

a Institute of Plant Protection, Hebei Academy of Agricultural and Forestry Sciences, Baoding, Hebei Province, China

b Biological Control of Pests Research Unit, The National Biological Control Laboratory, USDA-ARS-MSA, Stoneville, MS, USA
} 
the search for alternatives in the control of plant diseases caused by Pythium spp.

Efforts have been made in the search for biological and other natural means for integrated pest management (IPM) programs to manage Pythium diseases efficiently. Biological control efforts mainly focus either on utilizing a single strain of a microorganism or on introducing a group of microorganisms through composts. ${ }^{6-9}$ It has been proven that Trichoderma spp. and other microorganisms can be used to control or suppress soilborne plant pathogens, and to promote plant growth. ${ }^{9-16}$ Natural products can also be used to control plant diseases. These products include organic compounds and a variety of plant extracts. ${ }^{17}$ Natural bioactive products can be used as leads for the synthesis of a new generation of safe pesticides. The red imported fire ant, Solenopsis invicta Buren (Hymenoptera: Formicidae), is an invasive ant species introduced into the United States in the late 1930s. According to recent reports, S. invicta is distributed in many countries and areas and affects humans, wildlife, crops and livestock, causing billions of dollars in losses. ${ }^{18-20}$ In spite of the damage and economical loss, the alkaloid-rich venom produced by the red imported fire ant might be used against plant pathogens such as P. ultimum. The venom chemistry of the red imported fire ant has been previously characterized and described by various authors. ${ }^{21-24}$ The alkaloid fraction of the venom of $S$. invicta contains mainly 2-methyl-6-alkyl or -alkenyl piperidines, known as solenopsins. Although piperidine alkaloids had long been believed to be the only alkaloids in S. invicta, Chen et al. ${ }^{25,26}$ recently identified six piperideine alkaloids from $S$. invicta, its sister species, $S$. richteri, and their hybrid, including 2-methyl-6-tridecenyl-6-piperideine, 2-methyl6-tridecyl-6-piperideine, 2-methyl-6-pentadecenyl-6-piperideine, 2-methyl-6-pentadecyl-6-piperideine, 2-methyl-6-heptadecenyl6-piperideine and 2-methyl-6-heptadecyl-6-piperideine. Therefore, it is clear that the venom alkaloids extracted from the red imported fire ant consist of two groups of alkaloids: piperidine and piperideine alkaloids.

The insecticidal and antibiotic properties of the raw venom were discovered in the late 1950 s. $^{27}$ The venom was highly toxic to the fruit fly, the housefly, a termite species, the boll weevil, the rice weevil and two species of mites. Using a paper disc method, Blum et al. ${ }^{27}$ demonstrated that a $1 / 50$ dilution of the venom effectively inhibited the growth of Micrococcus pyogenes, Streptococcus pyogenes, Escherichia coli, Lactobacillus casei and a variety of molds. Gram-positive bacteria were more sensitive to piperidine alkaloids than gram-negative ones. ${ }^{28}$ Solenopsis invicta venom alkaloids also inhibited the germination and hyphal development of the entomopathogenic fungi Beauveria bassiana AF-4, B. bassiana 447, monosporal isolates of Metarhizium anisopliae and Paecilomyces fumosoroseus. ${ }^{29}$ No research efforts have been made to study the activities of venom alkaloids against plant pathogenic oomycetes such as Pythium spp. or the potential application of the piperidine and piperideine alkaloids to plant disease control. This study is the first to report on the use of purified piperidine and piperideine alkaloids from the red imported fire ant against plant pathogenic P. ultimum in the laboratory and the application of piperideine alkaloids in the control of pre- and post-emergence damping-off of cucumber caused by P. ultimum in the greenhouse.

\section{MATERIALS AND METHODS}

\subsection{Extraction and purification of piperidine and piperideine} alkaloids

Workers $(2.5 \mathrm{~g})$ of the imported fire ant were extracted in $15 \mathrm{~mL}$ of hexane in a $50 \mathrm{~mL}$ beaker 3 times. The pooled extract was then concentrated to about $0.5 \mathrm{~mL}$ under air flow. A flash chromatography system (Isolera Four; Biotage, LLC, Charlotte, NC) with a SNAP silica gel cartridge $(10 \mathrm{~g})$ was used to isolate and purify the piperidine and piperideine alkaloids. The UV detector wavelengths for the flash chromatography were $254 \mathrm{~nm}$ for channel 1 and $280 \mathrm{~nm}$ for channel 2 . The cartridge was first equilibrated with $45 \mathrm{~mL}$ of hexane before the sample was loaded. A gradient of hexane and acetone was used as a mobile phase at a flow rate of $12 \mathrm{~mL} \mathrm{~min}{ }^{-1}$. Acetone was increased from 0.0 to $100 \%$ within $19 \mathrm{~min}$. The fraction collection interval was $6 \mathrm{~mL}$. Fractions 17 to 22 were pooled and found to contain piperideine alkaloids, and fractions 38 to 70 contained piperidine alkaloids. Chromatograms and mass spectra of each alkaloid component are shown in the supporting information (Figs S1 to S7 for piperideine alkaloids and Figs S8 to S16 for piperidine alkaloids). The purity was $99.8 \%$ for piperidine alkaloids and $87.8 \%$ for piperideine alkaloids

\subsection{Inhibitory activity of piperidine and piperideine} alkaloids against mycelium growth of $\boldsymbol{P}$. ultimum

Plant pathogenic $P$. ultimum 214-04 was kindly provided by $\mathrm{Dr}$ David Ingram, Central Mississippi Research and Extension Center, Mississippi State University. This strain was isolated from tomato (variety 'Trust') in Newton County, Mississippi. This pathogen was maintained on potato dextrose agar (PDA) (Becton Dickinson \& Company, Sparks, MD) plates (each contained $20 \mathrm{~mL}$ of PDA). After $30 \mathrm{~h}$ incubation at $28^{\circ} \mathrm{C}, P$. ultimum culture discs $(5 \mathrm{~mm}$ in diameter) were cut from the growing edge of the colonies. Each culture disc was placed at the center of a freshly made PDA plate.

Fisherbrand P8 filter paper (Fisher Scientific, Pittsburgh, PA) was used to make $5 \mathrm{~mm}$ discs for carrying venom piperidine or piperideine alkaloids in acetone solutions. The paper discs were sterilized by autoclave at $121^{\circ} \mathrm{C}$ for $30 \mathrm{~min}$. The sterile filter paper discs were placed in a glass petri dish, and $5 \mu \mathrm{L}$ of acetone solution

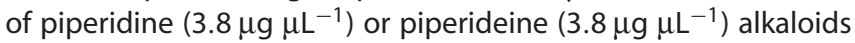
was added to each disc. Each filter paper disc had $19.0 \mu \mathrm{g}$ of either piperidine or piperideine alkaloids. After the acetone was evaporated under a laminar flow hood, four filter paper discs were placed on a PDA plate about $2.0 \mathrm{~cm}$ away from a $P$. ultimum culture disc at the 12,3,6, and 9 o'clock positions respectively. The $P$. ultimum culture disc was placed in the center of the plate. Filter paper discs with only $5 \mu \mathrm{L}$ of acetone were used as controls. Thus, there were two treatments (piperidine or piperideine alkaloids) and one control (acetone); each plate was one treatment. All plates were incubated at $28{ }^{\circ} \mathrm{C}$ with no light for $48 \mathrm{~h}$, and the inhibitory zones, the linear distance between the growth edge of a $P$. ultimum colony and the edge of a filter paper disc, were measured. This experiment was repeated 4 times.

\subsection{Stability of inhibitory activity of piperidine alkaloids stored at different temperature levels against mycelium growth of $\boldsymbol{P}$. ultimum}

Only piperidine alkaloids were used in the stability study. A quantity of $500 \mu \mathrm{L}$ of the acetone solution $\left(3.8 \mu \mathrm{g} \mu \mathrm{L}^{-1}\right.$ of piperidine alkaloids) was transferred into a $2 \mathrm{~mL}$ amber bottle, and the cap was screwed on tightly. Three bottles wrapped with aluminum foil comprised one storage package. Three packages were kept at 
4, 22 and $54^{\circ} \mathrm{C}$ respectively. Each storage temperature was one treatment. The solution was sampled 6 times at 2 week intervals for the packages stored at 4 and $22^{\circ} \mathrm{C}$ to conduct inhibitory assays. The packages stored at $54{ }^{\circ} \mathrm{C}$ were sampled twice at 2 and 4 weeks of storage. The paper disc method described in Section 2.2 was employed to study the stability of inhibitory activities of piperidine alkaloids against the mycelium growth of $P$. ultimum. This experiment was repeated 4 times.

\subsection{Inhibitory efficacy of piperidine alkaloid concentrations against mycelium growth of $\boldsymbol{P}$. ultimum}

The acetone solution containing piperidine alkaloids was blended in sterile deionized water (SDW) containing 0.1\% Tween-80 (Fisher Scientific, Fairlawn, NJ), and the mixture was then incorporated with PDA at $46^{\circ} \mathrm{C}$ to achieve $1.6,3.2,6.4,12.8$ and $25.6 \mu \mathrm{g}$ piperidine alkaloids $\mathrm{mL}^{-1}$ PDA medium. A quantity of $20 \mathrm{~mL}$ of medium was poured into one petri plate. Each piperidine alkaloid concentration was one treatment. The control had an equal amount of acetone- $0.1 \%$ Tween- 80 SDW. Pythium ultimum culture discs (5 mm in diameter, as described in Section 2.2) were then placed at the center of the plates with different concentrations of piperidine alkaloids. All plates were incubated at $28^{\circ} \mathrm{C}$ in the dark for $48 \mathrm{~h}$. The diameters of the $P$. ultimum colonies were measured. The inhibitory efficacy was calculated using the formula

$$
\text { Inhibitory efficacy }=\frac{\begin{array}{c}
\text { Colony diameter of control- } \\
\text { colony diameter of treatment }
\end{array}}{\text { Colony diameter of control }} \times 100
$$

This experiment was repeated 6 times.

\subsection{Inhibitory activity of piperidine alkaloids on the germination of sporangia of $\boldsymbol{P}$. ultimum}

The method for the production of $P$. ultimum sporangia published by Kageyama and Nelson ${ }^{30}$ was employed in this study with slight modifications. A P. ultimum culture disc ( $5 \mathrm{~mm}$ in diameter) was transferred to a defined mineral salt medium containing $0.1 \%$ soy lecithin $(\mathrm{SM}+\mathrm{L})$. After 5 days of incubation at $28^{\circ} \mathrm{C}$, the entire agar plate was leached for two consecutive 10 min intervals in a buffer (pH 5.8) containing $10 \mathrm{mM}$ of $\mathrm{Ca}\left(\mathrm{NO}_{3}\right)_{2}^{\bullet} 4 \mathrm{H}_{2} \mathrm{O}, 4 \mathrm{mM}$ of $\mathrm{MgSO}_{4}^{\bullet} 7 \mathrm{H}_{2} \mathrm{O}$ and $5 \mathrm{mM}$ of $\mathrm{KNO}_{3}$, followed by a final $3 \mathrm{~h}$ interval in darkness. This procedure was conducted in darkness, and the buffer was replaced after each leaching period. After the final leaching period, leachate was removed, and the agar plates were rinsed twice with SDW and kept at $24^{\circ} \mathrm{C}$ in darkness for 2 days. Sporangia were harvested by adding $500 \mu \mathrm{L}$ of SDW per plate and scraping sporangia from the surface of the culture. Sporangia suspensions were filtered through sterile cheesecloth, centrifuged 3 times at $6000 \mathrm{rpm}$ and washed twice with SDW. Potato dextrose broth (PDB) (Becton Dickinson) was added after the final centrifugation to adjust the sporangia density to $1 \times 10^{5}$ sporangia $\mathrm{mL}^{-1}$ PDB using a Neubauer Brightline hemacytometer (Hausser Scientific Co., Horsham, PA).

The acetone solution of piperidine alkaloids $\left(3.8 \mu \mathrm{g} \mu \mathrm{L}^{-1}\right)$ was first adjusted to $256 \mu \mathrm{g} \mathrm{ml}^{-1}$ by mixing with $0.1 \%$ Tween-80 SDW. Serial dilutions were made to dilute the $256 \mu \mathrm{g} \mathrm{ml}^{-1}$ suspension to achieve concentrations of $8.0,16.0,32.0,64.0$ and $128.0 \mu \mathrm{g}$ piperidine alkaloids $\mathrm{mL}^{-1}$ by incorporating with $0.1 \%$ Tween-80 SDW. A quantity of $1 \mathrm{~mL}$ of each concentration of piperidine alkaloids and the control was then mixed with $4.0 \mathrm{~mL}$ of PDB containing $1 \times 10^{5}$ sporangia $\mathrm{mL}^{-1}$ in a $50 \mathrm{~mL}$ centrifuge tube. The final concentrations of piperidine alkaloids in the PDB were
$0.0,1.6,3.2,6.4,12.8,25.6$ and $51.2 \mu \mathrm{g} \mathrm{ml}^{-1}$ respectively. Each piperidine alkaloid concentration was one treatment. The control was acetone- $0.1 \%$ Tween- 80 SDW only. All centrifuge tubes were incubated at $28{ }^{\circ} \mathrm{C}$ for $48 \mathrm{~h}$, and samples were taken to count the germination of sporangia under a light microscope. A total of 100-200 sporangia were counted for each piperidine alkaloid concentration, and sporangia were considered to have germinated when a developing germ tube was visible. Then the germination percentage was calculated for data analysis. Three samples were taken from each piperidine alkaloid concentration, and this experiment was repeated twice.

\subsection{Control of cucumber damping-off caused by $P$. ultimum using piperideine alkaloids in the greenhouse}

Redi-Earth plug and seedling mix (Sun Gro Horticulture Distribution Inc., Bellevue, WA) was used as growth medium. This mix was specially designed for small-type propagation in small containers, and was formulated with fine Canadian Sphagnum peat moss, vermiculite, starter nutrient charge (with gypsum), dolomitic limestone and a long-lasting wetting agent. The growth mix was autoclaved twice at $121^{\circ} \mathrm{C}$ for $1 \mathrm{~h}$ at $24 \mathrm{~h}$ intervals.

Certified organic cucumber (Cucumis sativus L.) seeds (Straight 8; Bar Farm Service Inc., Bay, MI) were used in this experiment. Germination of cucumber seeds was $100 \%$ on water agar plates at $22 \pm 1^{\circ} \mathrm{C}$. Cucumber seeds were surface disinfected by soaking in $0.5 \mathrm{~mL} \mathrm{NaOCl} \mathrm{L}^{-1}$ for $5 \mathrm{~min}$ and then rinsed with SDW.

Preliminary studies showed that soaking seeds with different concentrations of piperidine alkaloids did not provide any control, but drench treatment with piperidine alkaloids significantly improved the seedling emergence and seedling heights. Therefore, drench treatments were conducted with piperideine alkaloids in a greenhouse with two treatments and four controls. Pythium ultimum was grown on the PDA plates for 5 days at $28^{\circ} \mathrm{C}$ in the dark. Two mycelium discs (5 $\mathrm{mm}$ in diameter) were excised from the growing edge of a colony, transferred to the surface of the sterile growth mix ( $2 \mathrm{~cm}$ in depth) in a small growth container $\left(7.5 \times 5.5 \times 5.5 \mathrm{~cm}^{3}\right)$ and covered with a layer of sterile growth mix $(1 \mathrm{~cm})$. Cucumber seeds were placed on the surface of the inoculated growth mix and covered with $1 \mathrm{~cm}$ of growth mix. Ten seeds were sowed in each growth container, which had $3 \mathrm{~cm}$ growth mix in depth, and covered with $1 \mathrm{~cm}$ of growth mix as described above. Subsequently, $3 \mathrm{~mL}$ of piperideine alkaloids in acetone $-0.1 \%$ Tween- 80 SDW suspension at a concentration of $18.8 \mu \mathrm{g} \mathrm{ml}^{-1}$ (total of $56.5 \mu \mathrm{g}$ of piperideine alkaloids) and $188.4 \mu \mathrm{g} \mathrm{ml}^{-1}$ (total of $565.2 \mu \mathrm{g}$ of piperideine alkaloids) was applied to the surface of the growth mix in each container. The two treatments and four controls were as follows:

1. Control 1 had no $P$. ultimum, and only $3 \mathrm{~mL}$ of acetone $-0.1 \%$ Tween-80 SDW containing no piperideine alkaloids was applied to the surface of the growth mix in each container after sowing.

2. Control 2 had $P$. ultimum inoculum, and $3 \mathrm{~mL}$ of acetone $-0.1 \%$ Tween-80 SDW containing no piperideine alkaloids was applied to the surface of the growth mix in each container after sowing.

3. Control 3 had no P. ultimum, and $3 \mathrm{~mL}$ of acetone $-0.1 \%$ Tween-80 SDW containing $56.5 \mu \mathrm{g}$ of piperideine alkaloids was applied to the surface of the growth mix in each container after sowing.

4. Control 4 had no P. ultimum, and $3 \mathrm{~mL}$ of acetone- $0.1 \%$ Tween80 containing $565.2 \mu \mathrm{g}$ of piperideine alkaloids was applied to the surface of the growth mix in each container after sowing. 
5. Treatment 1 had $P$. ultimum inoculum, and $3 \mathrm{~mL}$ of acetone- $0.1 \%$ Tween- 80 containing $56.5 \mu \mathrm{g}$ of piperideine alkaloids was applied to the surface of the growth mix in each container after sowing.

6. Treatment 2 had $P$. ultimum inoculum, and $3 \mathrm{~mL}$ of acetone- $0.1 \%$ Tween- 80 containing $565.2 \mu \mathrm{g}$ of piperideine alkaloids was applied to the surface of the growth mix in each container after sowing.

The growth containers were then placed in trays on greenhouse benches, and water was added to the trays as needed. The temperature range in the greenhouse was $18-25^{\circ} \mathrm{C}$, and the relative humidity $(\mathrm{RH})$ was maintained at $60-90 \%$. The seedling stands were counted, and seedling heights were measured 20 days after sowing using the methods described by Chen and Nelson. ${ }^{9}$ The photoperiod was not controlled. Each treatment had one container with ten seeds, and this study was repeated 3 times.

\subsection{Statistical analysis}

Experimental design was a randomized complete block (RCB) for all experiments. Data were subjected to analysis of variance (ANOVA) and regression analysis using general linear mixed model procedures in SAS. ${ }^{31}$ Values were presented as means of replicated experiments and subjected to the least-squares post hoc test to identify significant differences among treatments at the $5 \%$ probability level. Analysis performed on each experiment was as follows:

- 2.2 - ANOVA followed by mean comparisons was performed for RCB with two treatments and four replications.

- 2.3 - ANOVA followed by mean comparisons was performed for a split-plot arrangement where the main unit was an RCB with three temperature treatments and the subunit treatment was a repeated measure over time.

- 2.4 and 2.5 - regression analysis was performed for inhibitory effects against mycelium growth (2.4) or sporangium germination (2.5) as a function of concentration of piperidine alkaloids.

- 2.6 - ANOVA followed by mean comparisons was performed for RCB with six treatments and three replications.

\section{RESULTS}

\subsection{Inhibitory activity of piperidine and piperideine} alkaloids against mycelium growth of $\boldsymbol{P}$. ultimum

Acetone had no inhibitory effect against mycelium growth of $P$. ultimum; therefore, results from the acetone treatment were omitted from the statistical analysis. Both piperidine and piperideine alkaloids significantly inhibited mycelium growth of $P$. ultimum (Fig. 1). There was no significant difference in inhibitory effects between these two alkaloids $(P>0.05)$.

\subsection{Stability of inhibitory activity of piperidine alkaloids stored at different temperatures against mycelium growth of P. ultimum}

Results indicated that storage temperature levels had no significant effects on the inhibitory activity of piperidine alkaloids $(P>0.05)$ (Fig. 2$)$. The inhibitory activity was significantly improved in the first weeks of storage $\left(\mathrm{df}_{\text {num }}=6, \mathrm{df}_{\mathrm{den}}=59\right.$, $F=3.71, P<0.05)$. The inhibitory activity of piperidine alkaloids was quite stable from 2 to 12 weeks of storage at 4 and $22^{\circ} \mathrm{C}$. There was a decrease in inhibitory activity of piperidine alkaloids after 4 weeks of storage at $54^{\circ} \mathrm{C}$. However, this decrease was not statistically significant $(P>0.05)$.

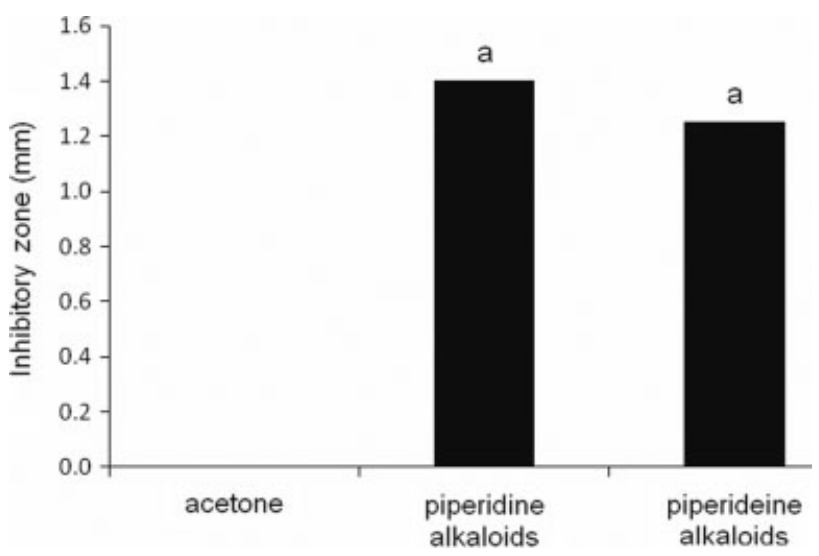

Figure 1. Inhibitory effects of piperidine and piperideine alkaloids from the venom of the red imported fire ant (Solenopsis invicta) on mycelium growth of Pythium ultimum on potato dextrose agar (PDA) plates incubated at $28^{\circ} \mathrm{C}$ for $48 \mathrm{~h}$; a paper disc method was used; each disc had $19.0 \mu \mathrm{g}$ of either piperidine or piperideine alkaloids. The purity was $99.8 \%$ for piperidine alkaloids and $87.8 \%$ for piperideine alkaloids. Values are the means of four replicates. Because acetone had no inhibitory effect against mycelium growth of $P$. ultimum, acetone treatment was omitted from the statistical analysis. Means with different letters are significantly different $(P<0.05)$

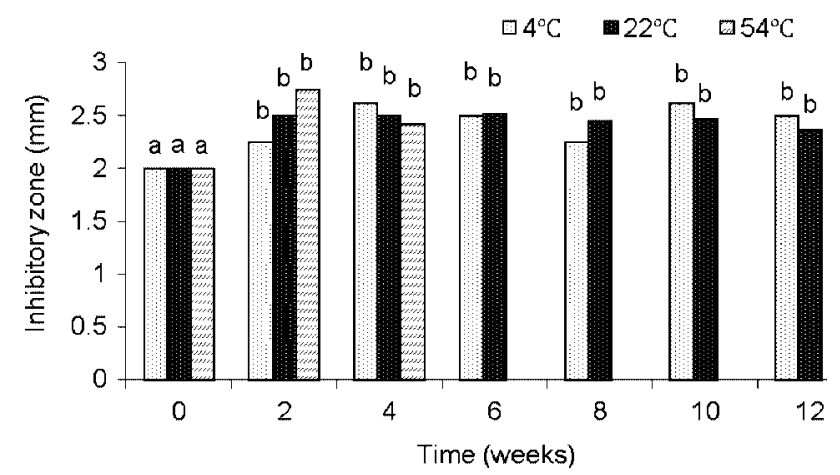

Figure 2. Effects of storage temperatures on the inhibitory activity of piperidine alkaloids (purity $=99.8 \%$ ) from the venom alkaloids of the red imported fire ant (Solenopsis invicta) against mycelium growth of Pythium ultimum on potato dextrose agar (PDA) plates over time; the paper disc method was utilized. Values are the means of four replicates. Means with different letters across the sampling time are significantly different $(P<0.05)$

\subsection{Inhibitory efficacy of piperidine alkaloid concentrations} against mycelium growth of $P$. ultimum

The inhibitory efficacy against mycelium growth of $P$. ultimum was positively correlated with the concentrations of piperidine alkaloids in the PDA medium $\left(R^{2}=0.8869, y=2.4822 x+7.7279\right)$ (Fig. 3). In the tested concentration range, higher concentrations demonstrated higher inhibitory efficacy. Based on the positive linear equation, the inhibitory $\mathrm{EC}_{50}=17.0 \mathrm{\mu g} \mathrm{m}^{-1}$.

\subsection{Inhibitory activity of piperidine alkaloids against sporangium germination of $P$. ultimum}

Germination of sporangia of $P$. ultimum was negatively correlated with the concentration increase of piperidine alkaloids in PDB $\left(R^{2}=0.8458, y=-1.2871 x+65.775\right)$ (Fig. 4). Sporangia of $P$. ultimum were sensitive to the presence of piperidine alkaloids. Based on the negative linear equation, the inhibitory activity 


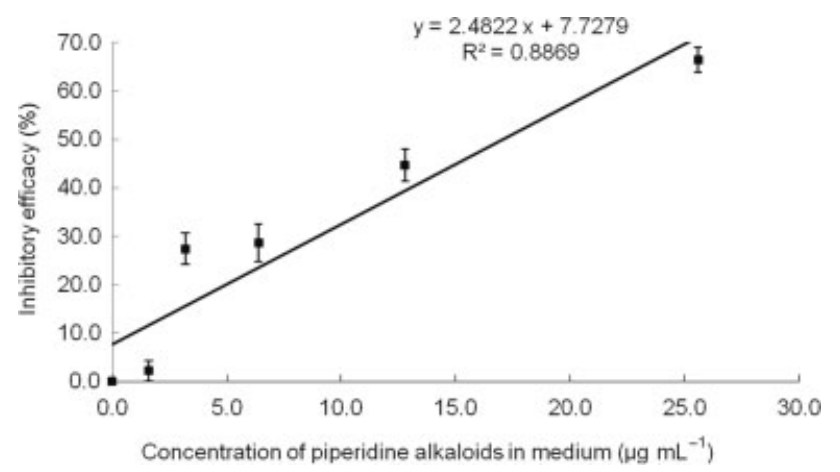

Figure 3. Inhibitory efficacy against mycelium growth of Pythium ultimum on potato dextrose agar (PDA) plates containing different concentrations of piperidine alkaloids (purity $=99.8 \%$ ) from the red imported fire ant Solenopsis invicta. The acetone solution containing piperidine alkaloids was mixed with sterile deionized water (SDW) containing $0.1 \%$ Tween-80, and the mixture was then incorporated into PDA at $46^{\circ} \mathrm{C}$ to achieve different concentrations of piperidine alkaloids $\mathrm{mL}^{-1}$ PDA medium. Values are the means of six replicates, and bars represent standard errors.

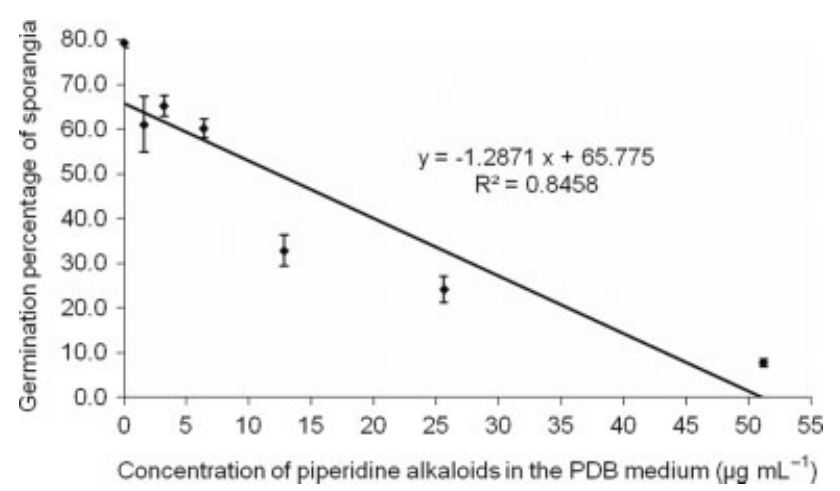

Figure 4. Germination of sporangia of Pythium ultimum in potato dextrose broth (PDB) containing different concentrations of piperidine alkaloids (purity $=99.8 \%$ ) from the red imported fire ant Solenopsis invicta. The acetone solution of piperidine alkaloids was diluted with $0.1 \%$ Tween- 80 in sterile deionized water, and was then mixed with PDB to achieve different concentrations of piperidine. The incubation was conducted at $28{ }^{\circ} \mathrm{C}$ for $48 \mathrm{~h}$. Values are the means of six samples of two replicates, and bars represent standard errors.

$\mathrm{EC}_{50}=12.3 \mu \mathrm{g} \mathrm{m}^{-1}$. Germination of sporangia was less than $10 \%$ when the piperidine alkaloid concentration reached $51.2 \mu \mathrm{g} \mathrm{ml}^{-1}$.

\subsection{Control of cucumber damping-off caused by $P$. ultimum using piperideine alkaloids in the greenhouse}

Results indicated that drenching treatment with both concentrations of piperideine alkaloids (18.8 and $188.5 \mu \mathrm{g} \mathrm{ml}^{-1}$ ) significantly improved the seedling emergence $\left(\mathrm{df}_{\text {num }}=5\right.$, $\left.\mathrm{df}_{\text {den }}=10, F=61.1, P<0.05\right)$ and seedling heights $\left(\mathrm{df}_{\text {num }}=5\right.$, $\mathrm{df}_{\text {den }}=10, F=27.27, P<0.05$ ) (Table 1). These results were comparable with the controls. There was no significant difference in disease control effects between these two concentrations of piperideine alkaloids $(P>0.05)$. Acetone- $0.1 \%$ Tween- 80 SDW with or without piperideine alkaloids at both concentrations had no adverse effects on the seedling emergence and seedling heights.

\section{DISCUSSION}

This study is the first report to show the inhibitory activity of both groups of venom alkaloids, piperidines and piperideines, against the soilborne plant pathogen P. ultimum. Although it was believed that control of Pythium diseases would eventually be achieved by the development of resistant or tolerant crop varieties, ${ }^{2}$ these efforts have not been fruitful owing to the wide host range of Pythium spp. and the unavailability of strong resistance. Dampingoff disease has been mainly controlled by seed treatment with chemical fungicides and cultural practices. Commercialization of Trichoderma spp.-based products to control damping-off caused by Pythium spp. has made considerable progress over the past two decades in the United States and in the developing countries. ${ }^{32,33}$ However, the commercialization of biological control products has been hindered by the difficulties existing in mass production, stabilization, formulation development and shelf life, as well as the registration process.

Natural products can be important in the search for alternatives in insect pest and plant disease management because of their enormous diversity. ${ }^{17}$ Dayan et al. ${ }^{34}$ reviewed natural products in detail, including plant extracts, antibiotics from microbes and plant disease resistance elicitors for the management of plant pathogens. The present laboratory results showed that both piperidine and piperideine alkaloids extracted from the red imported fire ant inhibited the mycelium growth of $P$. ultimum on PDA plates. Although statistically the inhibitory effects were significant, the inhibitory zones were small because the PDA medium used in the present studies might have absorbed certain amounts of either piperidine or piperideine alkaloids. Water agar should be used in future studies to avoid medium absorbency. It is the authors' understanding that piperidine alkaloids are more stable than piperideine alkaloids because piperideines have a double bond on their piperidine rings. It was also discovered that piperidine alkaloids were stable at room temperatures for 12 weeks. The inhibitory effects against mycelium growth of $P$. ultimum were positive in accordance with the concentrations of piperidine alkaloids. Higher concentrations resulted in better inhibitory effects, and the inhibitory $\mathrm{EC}_{50}=17.0 \mu \mathrm{g} \mathrm{ml}^{-1}$.

Pythium ultimum is a ubiquitous plant pathogen and one of the most pathogenic Pythium spp. on crop species, ${ }^{2}$ and it can survive in air-dried muck soil for 12 years. ${ }^{35}$ The ability of sporangia to persist under adverse conditions, coupled with their extraordinary capacity to avoid competition by rapid germination and rapid germ tube extension in response to low exogenous nutrients and by producing secondary sporangia and retracting and conserving protoplasm under starvation conditions, enables $P$. ultimum to occupy its soil ecological niche. Consequently, sporangia of $P$. ultimum function as one of the major survival structures in cultivated soils to provide inoculum. ${ }^{36}$ The present results indicated that sporangia were more sensitive than mycelium to the presence of piperidine alkaloids, and the inhibitory $\mathrm{EC}_{50}=12.3 \mu \mathrm{g} \mathrm{ml}^{-1}$. In the preliminary study it was found that drench treatment, $56.5 \mu \mathrm{g}$ of piperidine alkaloids per container, significantly improved seedling emergence and heights (data not shown). Use was made of 56.5 or $565.2 \mu \mathrm{g}$ of piperideine alkaloids per container as drench treatment in this study. This amount of piperideine alkaloids inhibited both mycelium growth and sporangium germination. Therefore, seedling emergence and seedling heights of cucumber treated with piperideine alkaloids were comparable with those of the controls (Table 1). There were no significant differences in inhibitory activities between these two piperideine alkaloid concentrations; therefore, the 
Table 1. Control of cucumber (Cucumis sativus) damping-off caused by Pythium ultimum using drench treatments with piperideine alkaloids (purity $=87.8 \%$ ) extracted from the red imported fire ant (Solenopsis invicta). The relative humidity in the $25-28{ }^{\circ} \mathrm{C}$ greenhouse was maintained at $60-90 \%$. The seedling stands were counted and seedling heights were measured 20 days after sowing ${ }^{a, b}$

\begin{tabular}{|c|c|c|c|}
\hline Treatment & Description & Seedling emergence ${ }^{c}(\%)($ mean $\pm S E)$ & Seedling height ${ }^{d}(\mathrm{~cm})($ mean \pm SE) \\
\hline Control 1 & $\begin{array}{l}\text {-P. ultimum } \\
\text { - piperideines }\end{array}$ & $93.33 \pm 3.33 a$ & $11.54 \pm 0.54 \mathrm{a}$ \\
\hline Control 2 & $\begin{array}{l}+P . \text { ultimum } \\
\text { - piperideines }\end{array}$ & $33.3 \pm 3.33 b$ & $6.74 \pm 0.27 b$ \\
\hline Control 3 & $\begin{array}{l}\text {-P. ultimum } \\
\text { +piperideines } 56.5 \mu \mathrm{g}\end{array}$ & $96.67 \pm 3.33 a$ & $11.26 \pm 0.35 a$ \\
\hline Control 4 & $\begin{array}{l}\quad \text {-P. ultimum } \\
\text { +piperideines } 565.2 \mu \mathrm{g}\end{array}$ & $96.67 \pm 3.33 a$ & $11.48 \pm 0.45 a$ \\
\hline Treatment 1 & $\begin{array}{l}\text { +P. ultimum } \\
\text { +piperideines } 56.5 \mu \mathrm{g}\end{array}$ & $96.67 \pm 3.33 a$ & $11.60 \pm 0.22 \mathrm{a}$ \\
\hline Treatment 2 & $\begin{array}{c}\quad+P . \text { ultimum } \\
\text { +piperideines } 565.2 \mu \mathrm{g}\end{array}$ & $96.67 \pm 3.33 a$ & $11.76 \pm 0.20 \mathrm{a}$ \\
\hline $\begin{array}{l}{ }^{a} \text { Numbers ar } \\
\text { b Different let } \\
{ }^{c} \text { ANOVA follc } \\
P<0.05) \text {. } \\
\text { d ANOVA follc } \\
P<0.05) .\end{array}$ & $\begin{array}{l}\text { of three replicates and ar } \\
\text { column indicate a signific } \\
\text { an comparison showed t } \\
\text { an comparison showed } t\end{array}$ & $\begin{array}{l}\text { d with standard errors (SE). } \\
\text { nce at the } P<0.05 \text { level. } \\
\text { ents had significant effects on seedling } \\
\text { ents had significant effects on the seedl }\end{array}$ & $\begin{array}{l}\left(d f_{\text {num }}=5, d f_{\text {den }}=10, F=61.10,\right. \\
\left(d f_{\text {num }}=5, d f_{\text {den }}=10, F=27.27,\right.\end{array}$ \\
\hline
\end{tabular}

lower concentration of piperideine alkaloids could be used to control damping-off in the greenhouse. Drench treatment can be applied to hydroponic systems in greenhouse production to control damping-off caused by Pythium spp.

The present findings involving piperidine and piperideine alkaloids extracted from the red imported fire ant to control the most destructive damping-off diseases caused by $P$. ultimum may lead to the development of a new group of fungicidal chemicals. Further studies must focus on the synthesis of piperidine and piperideine alkaloids and on formulation development that may provide satisfactory control of damping-off caused by P. ultimum.

\section{ACKNOWLEDGEMENTS}

The technical assistance of Robert B Elliott and Alfred Martin is gratefully acknowledged. The authors thank Debbie Boykin, USDA-ARS-MSA, Stoneville, MS, for providing statistical assistance. Mention of trade names or commercial products in this article is solely for the purpose of providing specific information and does not imply recommendation or endorsement by the US Department of Agriculture. USDA is an equal opportunity provider and employer.

\section{SUPPORTING INFORMATION}

Supporting information may be found in the online version of this article.

\section{REFERENCES}

1 Hendrix FF and Campbell WA, Pythiums as plant pathogens. Annu Rev Phytopathol 11:77-98 (1973).

2 Martin FN and Loper JE, Soilborne plant diseases caused by Pythium spp.: ecology, epidemiology, and prospects for biological control. Crit Rev Plant Sci 18:111 - 181 (1999).

3 Sander PL, Failure of metalaxyl to control Pythium blight on turfgrass in Pennsylvania. Plant Dis 68:776-777 (1984).
4 Ruiz MJ and Marzin D, Genotoxicity of six pesticides by Salmonella mutagenicity test and SOS chromotest. Mutat Res 390:245-255 (1997).

5 Battershill JM and Fielder RJ, Mouse-specific carcinogens: an assessment of hazard and significance for validation of shortterm carcinogenicity bioassays in transgenic mice. Hum Exp Toxicol 17:193-205 (1998).

6 Benhamou N, Gagné S, Le Quéré D and Dehbi L, Bacterial-mediated induced resistance in cucumber: beneficial effect of the endophytic bacterium Serratia plymuthica on the protection against infection by Pythium ultimum. Phytopathology 90:45-56 (2000).

7 Fatemeh M, Björkman T and Harman GE, Seed treatment with Trichoderma harzianum alleviates biotic, abiotic and physiological stresses in germinating seeds and seedlings. Phytopathology 100:1213-1221 (2010).

8 Scheuerell SJ and Mahaffee WF, Compost tea as a container medium drench for suppressing seedling damping-off caused by Pythium ultimum. Phytopathology 94:1156-1163 (2004).

9 Chen MH and Nelson EB, Seed-colonizing microbes from municipal biosolids compost suppress Pythium ultimum damping-off on different plant species. Phytopathology 98:1012-1018 (2008).

10 Xue AG, Biological control of pathogens causing root rot complex in field pea using Clonostachys rosea strain ACM941. Phytopathology 93:329-335 (2003).

11 Harman GE, Petzoldt R, Comis A and Chen J, Interactions between Trichoderma harzianum strain T22 and maize inbred line Mo17 and effects of these interactions on diseases caused by Pythium ultimum and Colletotrichum graminicola. Phytopathology 94:147-153 (2004).

12 Harman GE, Overview of mechanisms and uses of Trichoderma spp. Phytopathology 96:190-194 (2006).

13 Howell CR, Cotton seeding preemergence damping-off incited by Rhizopus oryzae and Pythium spp. and its biological control with Trichoderma spp. Phytopathology 92:177-180 (2002).

14 Howell CR, Mechanisms employed by Trichoderma species in the biological control of plant diseases: the history and evolution of current concepts. Plant Dis 87:4-10 (2003).

15 Howell CR, Effect of seed quality and combination fungicide-Trichoderma spp. seed treatments on pre-and postemergence damping-off in cotton. Phytopathology 97:66-71 (2007).

16 Postma J, Geraats BPJ, Pastoor R and van Elsas JD, Characterization of the microbial community involved in the suppression of Pythium aphanidermatum in cucumber grown on rockwool. Phytopathology 95:808-818 (2005)

17 Jespers $A B K$ and De Waard MA, Natural products in plant protection. Eur J Plant Pathol 99:(Suppl. 3): 109-117 (1993). 
18 Wojcik DP, Allen CR, Brenner RJ, Forys EA, Jouvenaz DP and Lutz RS, Red imported fire ants: impact on biodiversity. Am Entomol 47:16-23 (2001).

19 Sánchez-Peña SR, Patrock RJW and Gilbert LA, The red imported fire ant is now in Mexico: documentation of its wide distribution along the Texas-Mexico border. Entomol News 116:363-366 (2005).

20 Gutrich JJ, VanGelder E and Loope L, Potential economic impact of introduction and spread of the red imported fire ant, Solenopsis invicta, in Hawaii. Environ Sci Policy 10:685-696 (2007).

21 MacConnell JG, Blum MS and Fales HM, Alkaloid from fire ant venom: identification and synthesis. Science 168:840-841 (1970).

22 MacConnell JG, Blum MS and Fales HM, The chemistry of fire ant venom. Tetrahedron 27:1129-1139 (1971).

23 Jones TH, Blum MS and Fales HM, Ant venom alkaloids from Solenopsis and Monomorium species, recent developments. Tetrahedron 38:1949-1958 (1982).

24 Leclercq S, Thirionet I, Broeders F, Daloze D, Vander Meer R and Braekman JC, Absolute configuration of Solenopsins, venom alkaloids of the fire ants. Tetrahedron 50:8465-8478 (1994).

25 Chen J, Cantrell CL, Shang HW and Rojas MG, Piperideine alkaloids from the poison gland of the red imported fire ant (Hymenoptera: Formicidae). J Agric Food Chem 57:3128-3133 (2009).

26 Chen J, Shang HW and Jin X, Interspecific variation of $\Delta^{1,6}$ piperideines in imported fire ants. Toxicon 55:1181-1187 (2010).

27 Blum MS, Walker JR, Callaham PS and Novak AF, Chemical, insecticidal, and antibiotic properties of fire ant venom. Science 128:306-307 (1958).

28 Jouvenaz DP, Blum MS and MacConnell JG, Antibacterial activity of venom alkaloids from the imported fire ant, Solenopsis invicta Buren. Antimicrob Agents Chemother 2:291-293 (1972).
29 Storey GK, Vander Meer RK, Boucias DG and McCoy CW, Effect of fire ant (Solenopsis invicta) venom alkaloids on the in vitro germination and development of selected entomogenous fungi. J Invertebr Pathol 58:88-95 (1991).

30 Kageyama K and Nelson EB, Differential inactivation of seed exudate stimulation of Pythium ultimum sporangium germination by Enterobacter cloacae influences biological control efficacy on different plant species. Appl Environ Microbiol 69:1114-1120 (2003).

31 Littell RC, Milliken GA, Stroup WW, Wolfinger RD and Schabenberger O, SAS for Mixed Models, 2nd edition. SAS Institute, Cary, NC (2006).

32 Jin $\mathrm{X}$, Hayes $\mathrm{CK}$ and Harman GE, Principles in the development of biological control system employing Trichoderma species against soil-borne plant pathogenic fungi, in Frontiers in Industry Mycology, ed. by Leatham GF. Chapman and Hall, Inc., New York, NY, pp. 174-195 (1992)

33 Harman GE, Obregón MA, Samuels GJ and Matteo L, Changing models for commercialization and implementation of biocontrol in the developing and the developed world. Plant Dis 94:928-939 (2010).

34 Dayan FE, Cantrell CL and Duke SO, Natural products in crop protection. Bioorg Med Chem 17:4022-4034.

35 Hoppe PE, Pythium species still viable after 12 years in air-dried muck soil. Phytopathology 56:1411 (1966).

36 Stanghellini ME and Hancock JG, The sporangium of Pythium ultimum as a survival structure in soil. Phytopathology 61:157-164 (1971). 


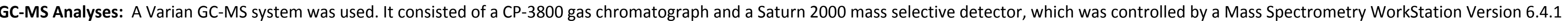

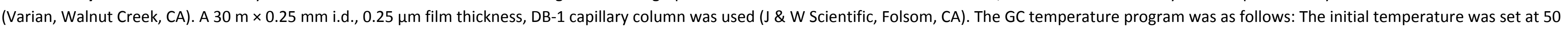

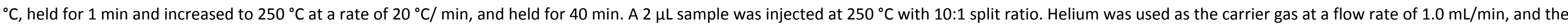
transfer line temperature was set at $200^{\circ} \mathrm{C}$. The mass spectrometer was operated at $70 \mathrm{eV}$ in the electron impact mode. 


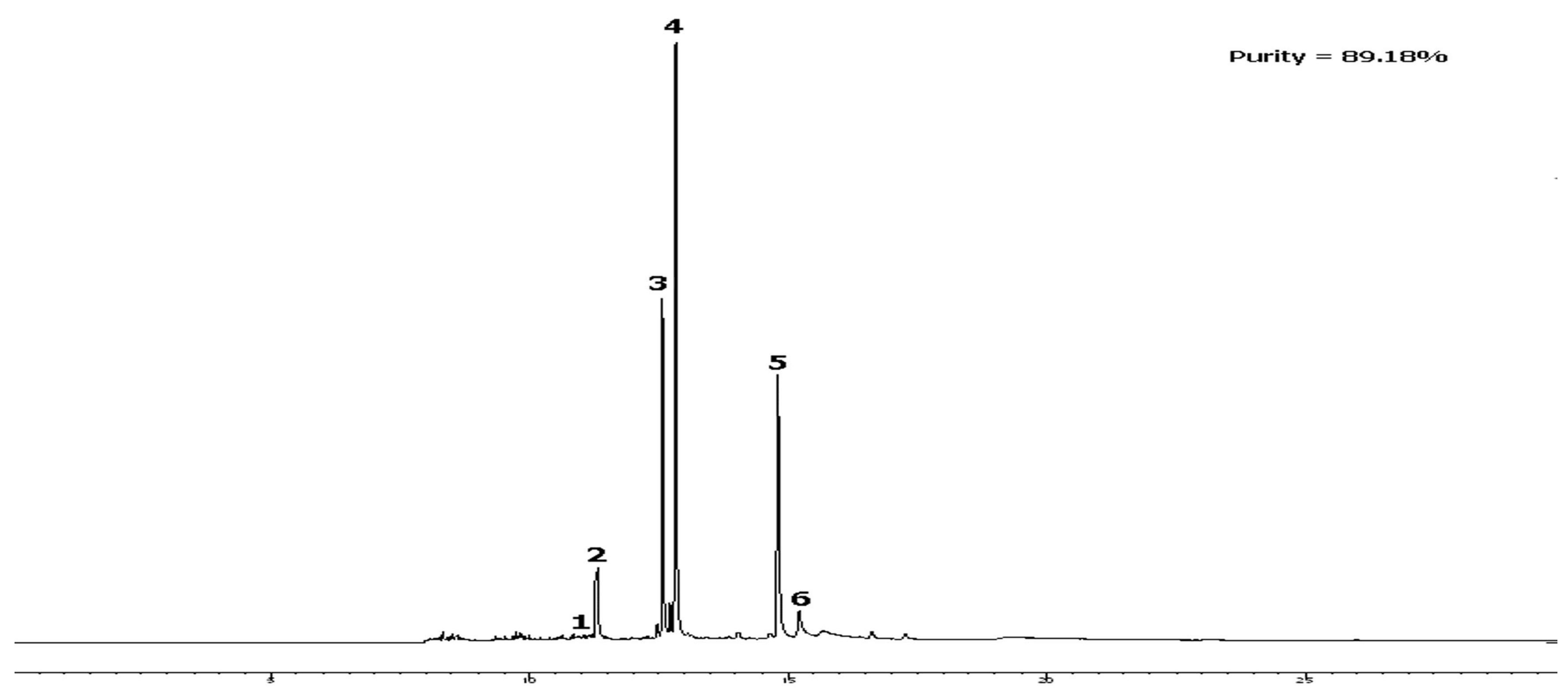

Figure S1. GC-MS-EI TIC of piperideine alkaloids (fractions 17-22 from flash chromatography)

Peak assignment:
1. 2-methyl-6-tridecenyl-6-piperideine (0.23\%)
2. 2-methyl-6-tridecyl-6-piperideine (4.30\%)
3. 2-methyl-6-pentadecenyl-6-piperideine (21.66\%)
4. 2-methyl-6-pentadecyl-6-piperideine (44.83\%)
5. 2-methyl-6-heptadecenyl-6-piperideine (24.94\%)
6. 2-methyl-6-heptadecyl-6-piperideine (4.03\%) 


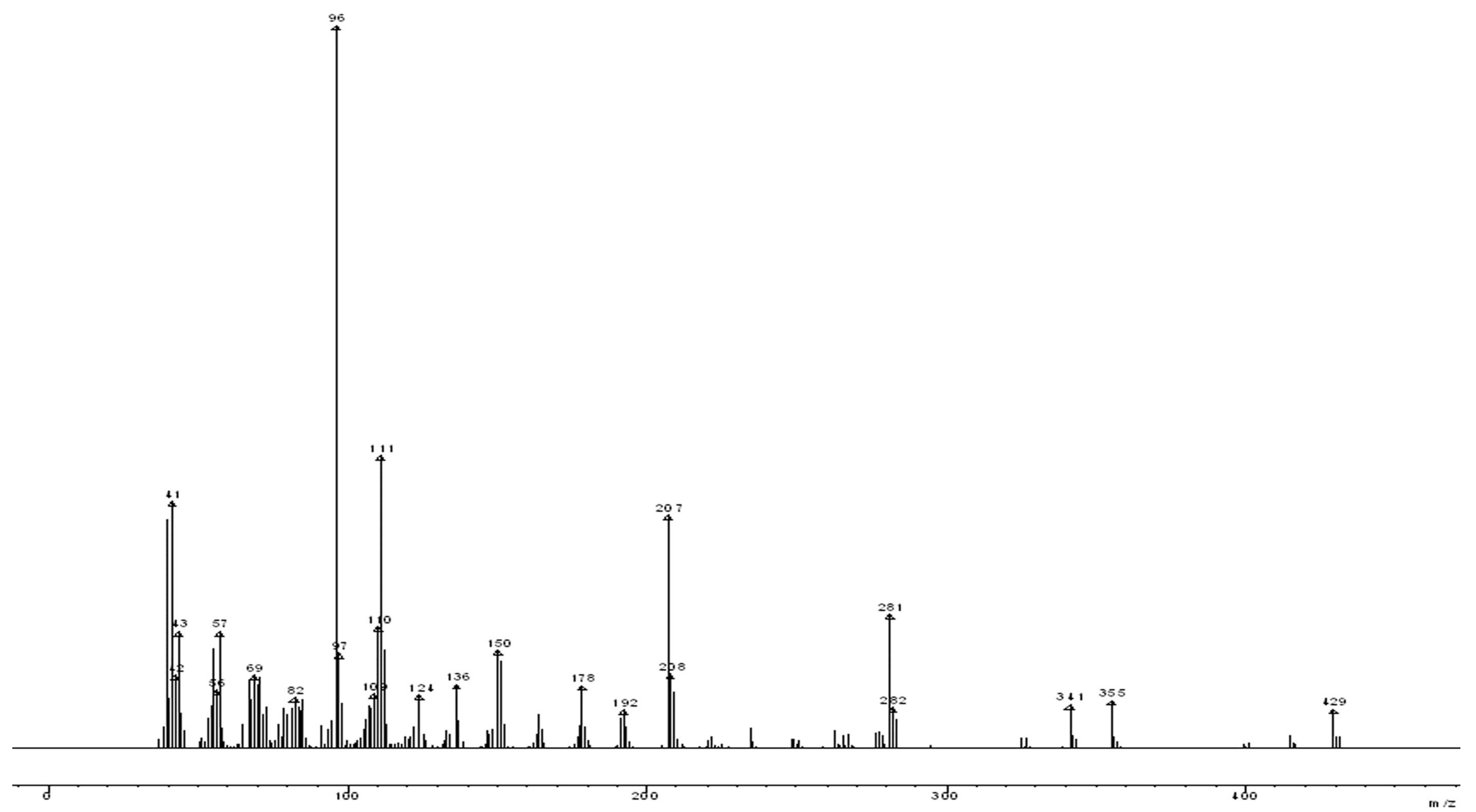

Figure S2. Mass spectrum of 2-methyl-6-tridecenyl-6-piperideine. 


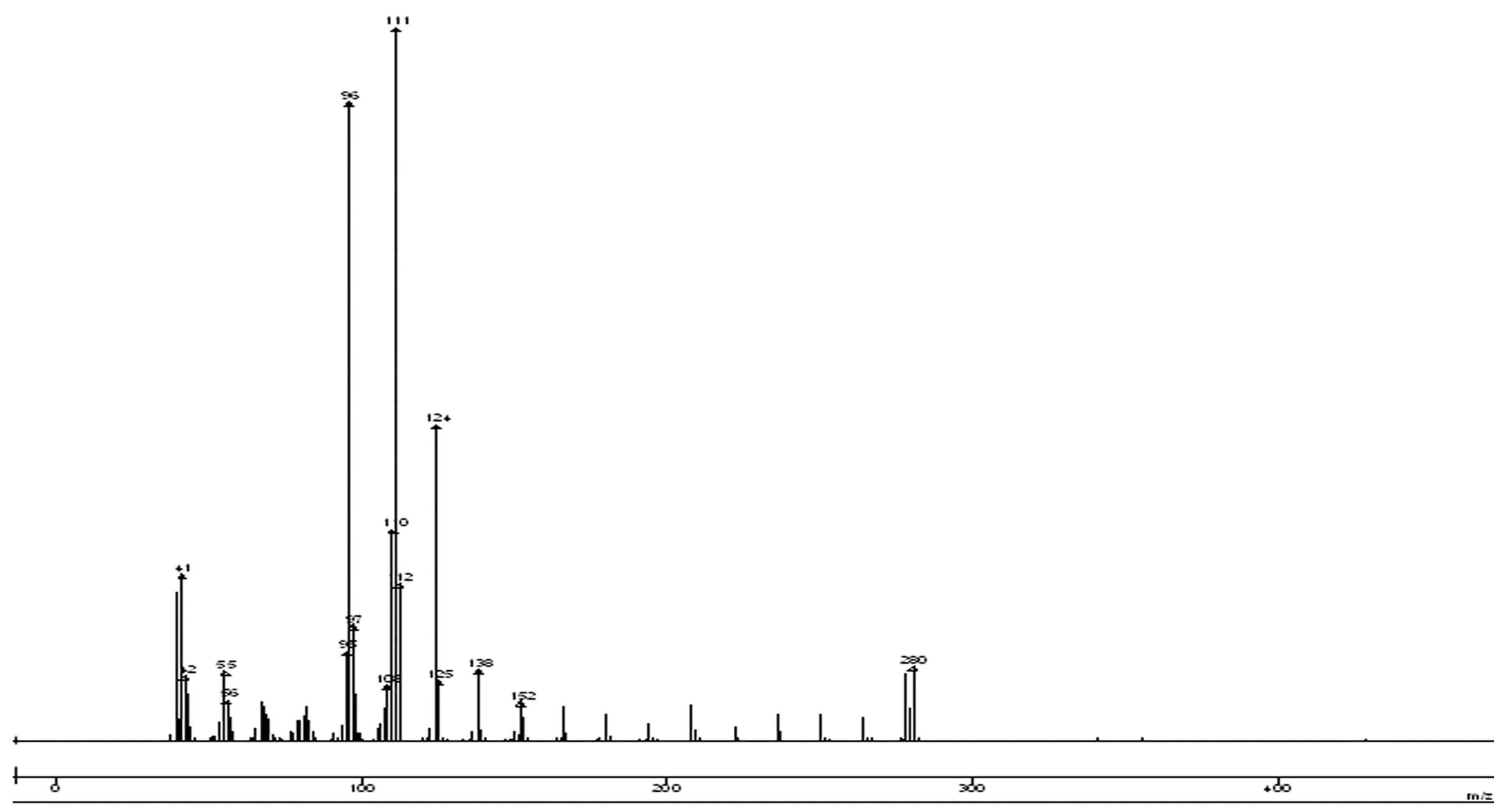

Figure S3. Mass spectrum of 2-methyl-6-tridecyl-6-piperideine. 


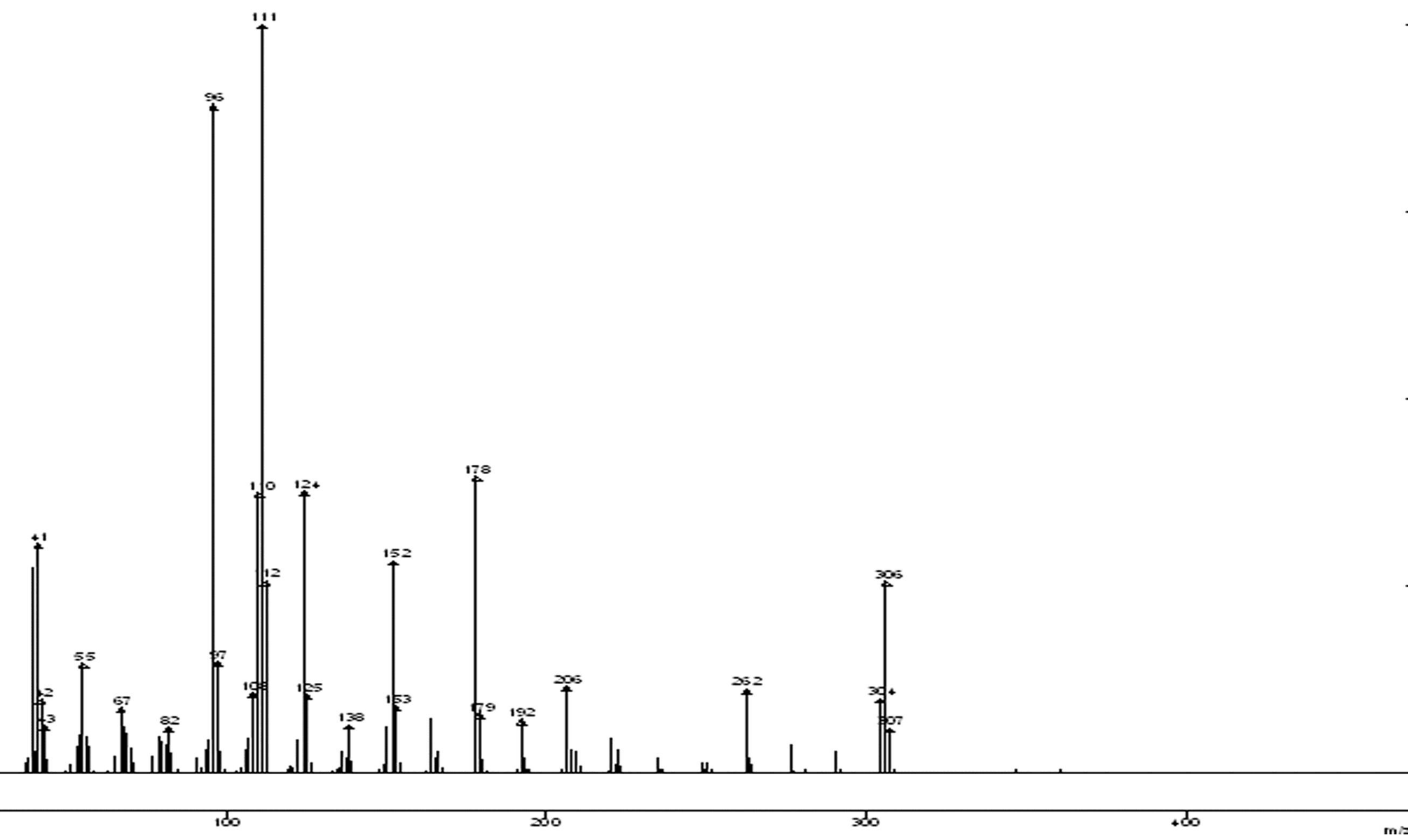

Figure S4. Mass spectrum of 2-methyl-6-pentadecenyl-6-piperideine 


$$
\text { لي }
$$




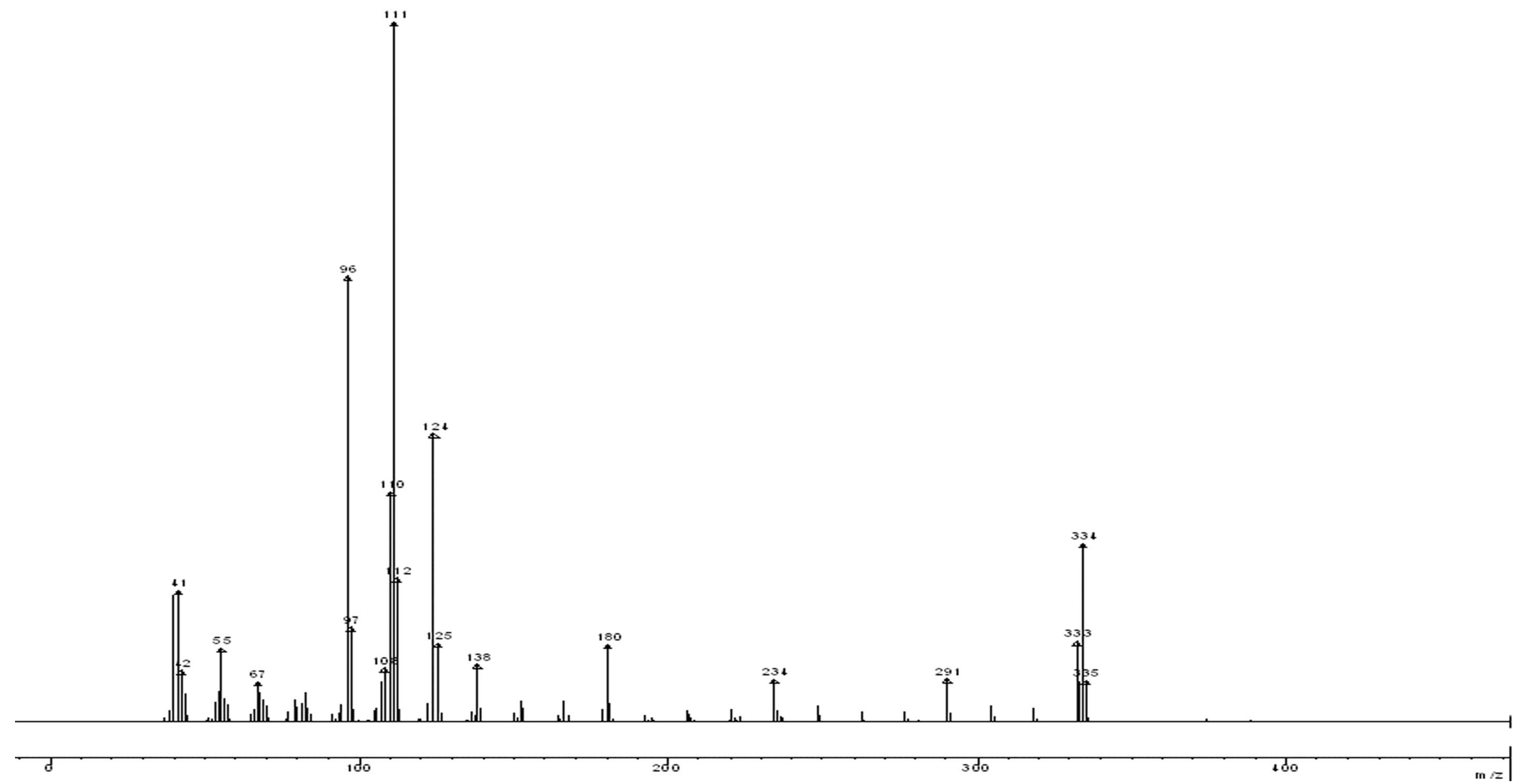

Figure S6. Mass spectrum of 2-methyl-6-heptadecenyl-6-piperideine 


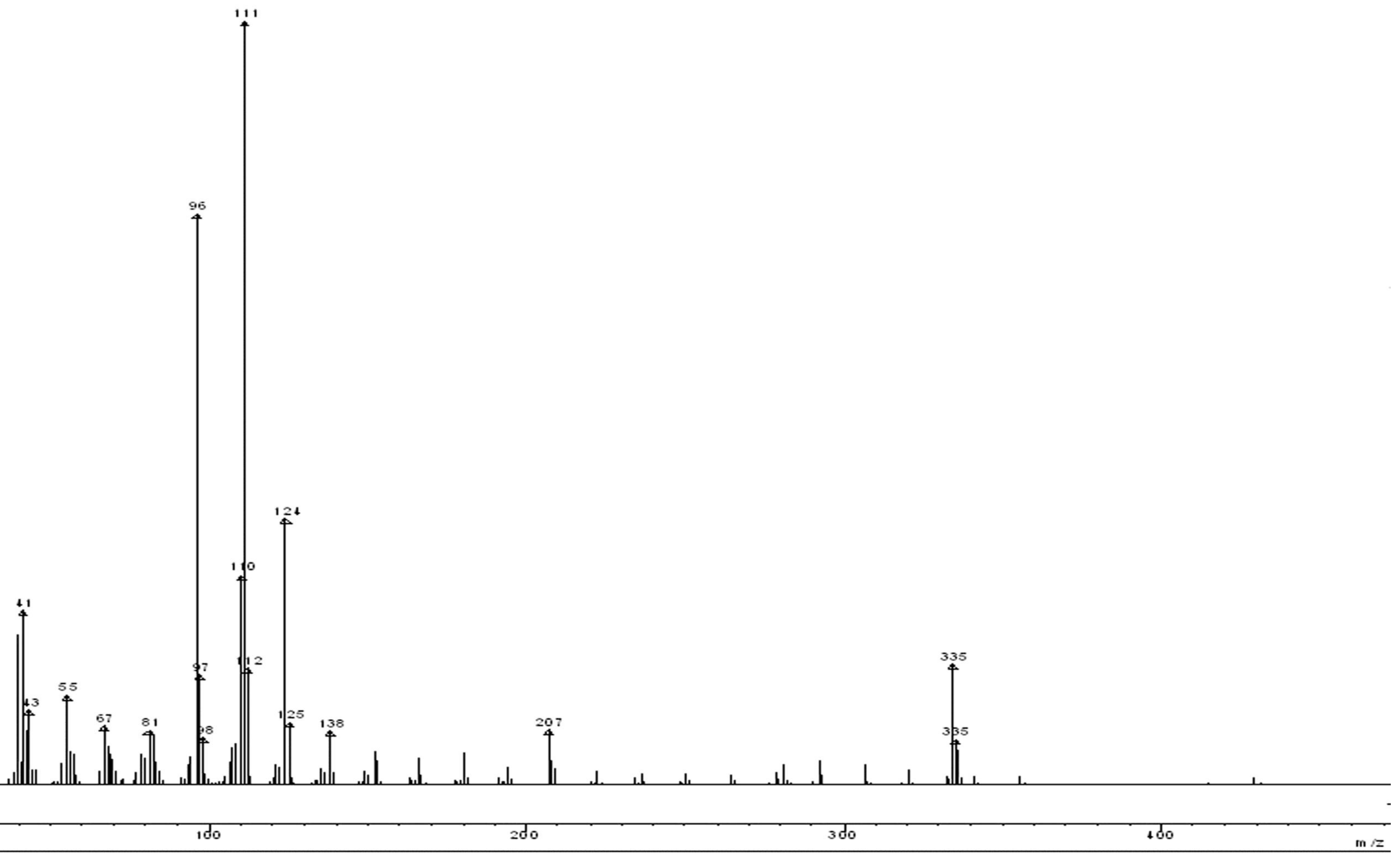

Figure S7. Mass spectrum of 2-methyl-6-heptadecyl-6-piperideine 


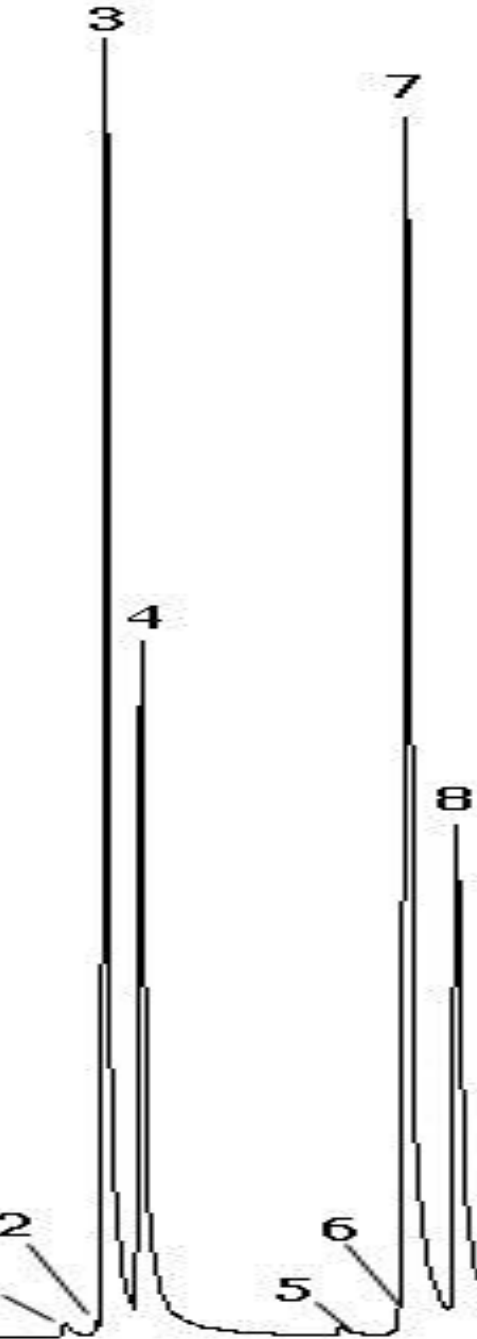

Purity $=99.790 / 0$

Figure S8. GC-MS-EI TIC of piperidine alkaloids (fractions 38-70 from flash chromatography)

Peak assignment:

1. cis-2-methyl-6-tridecenylpiperidine $(0.36 \%)$

2. cis-2-methyl-6-tridecylpiperidine (0.19\%)

3. trans-2-methyl-6-tridecenylpiperidine $(26.04 \%)$

4. tran-2-methyl-6-tridecylpiperidine (16.48\%)

5. cis-2-methyl-6-pentadecenylpiperidine $(0.33 \%)$

6. cis-2-methyl-6-pentadecylpiperidine $(0.053 \%)$

7. trans-2-methyl-6-pentadecenylpiperidine (36.10\%)

8. tran-2-methyl-6-pentadecylpiperideine (20.44\%) 


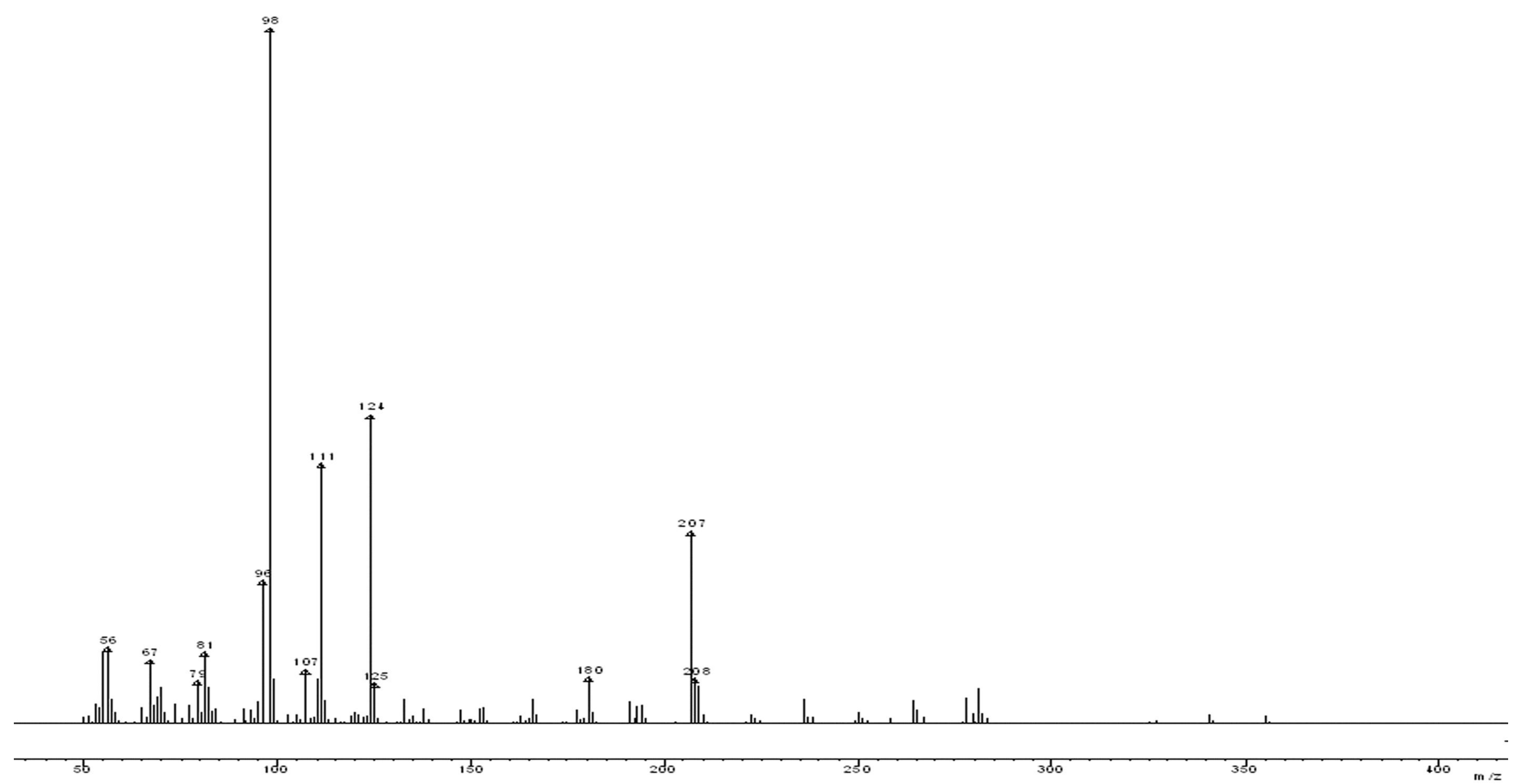

Figure S9. Mass spectrum of cis-2-methyl-6-tridecenylpiperidine 


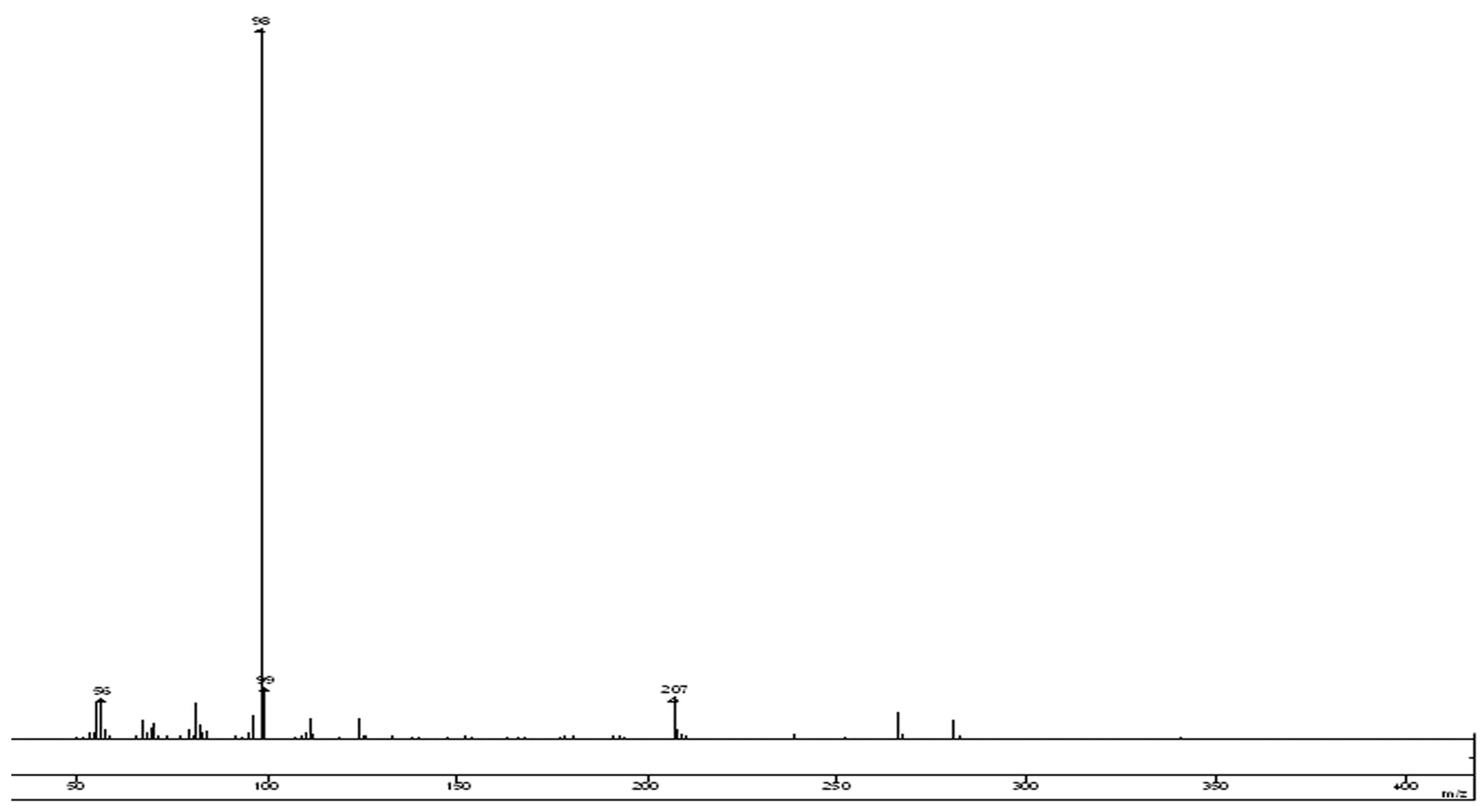

Figure S10. Mass spectrum of cis-2-methyl-6-tridecylpiperidine 


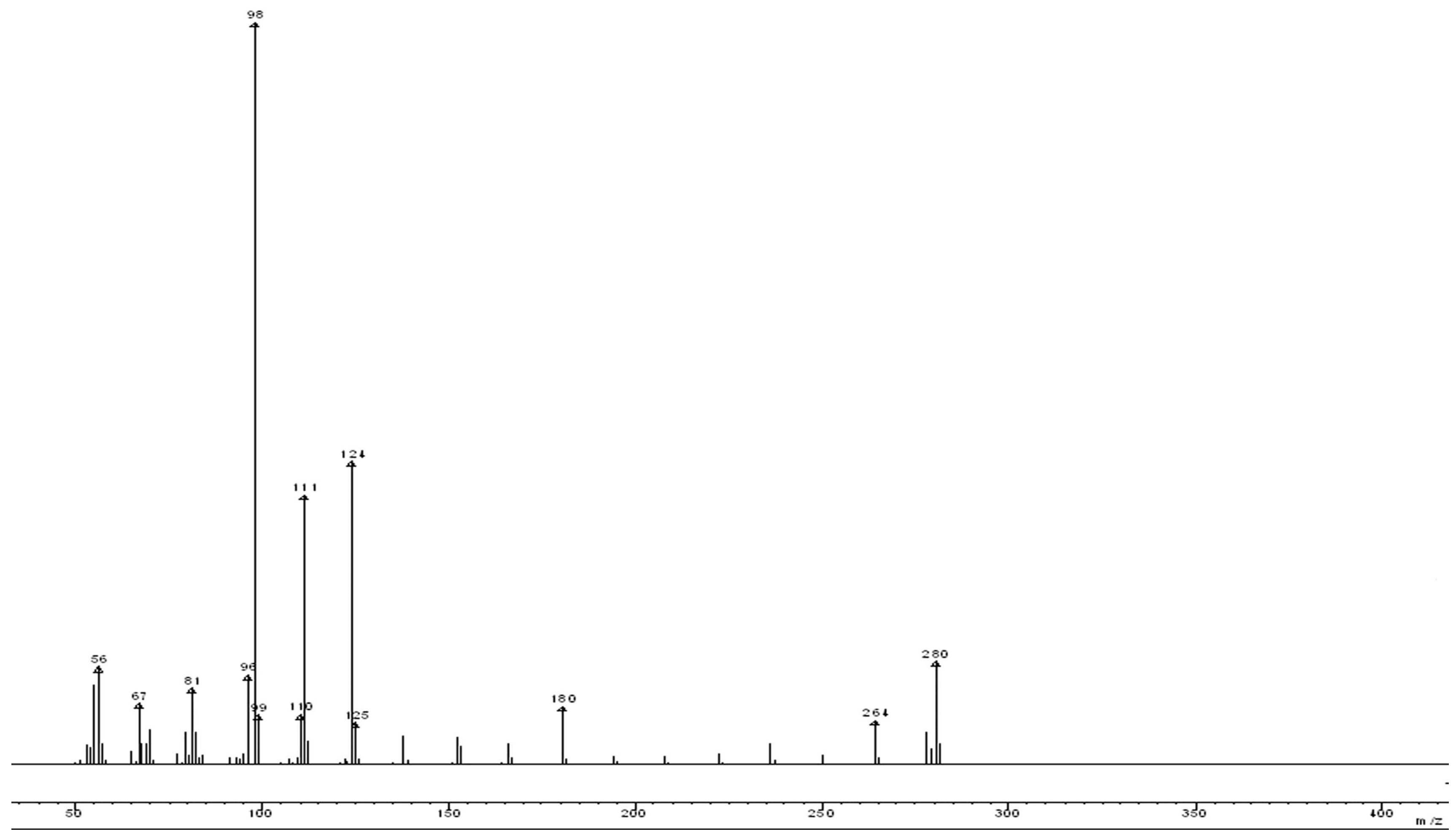

Figure S11. Mass spectrum of trans-2-methyl-6-tridecenylpiperidine 


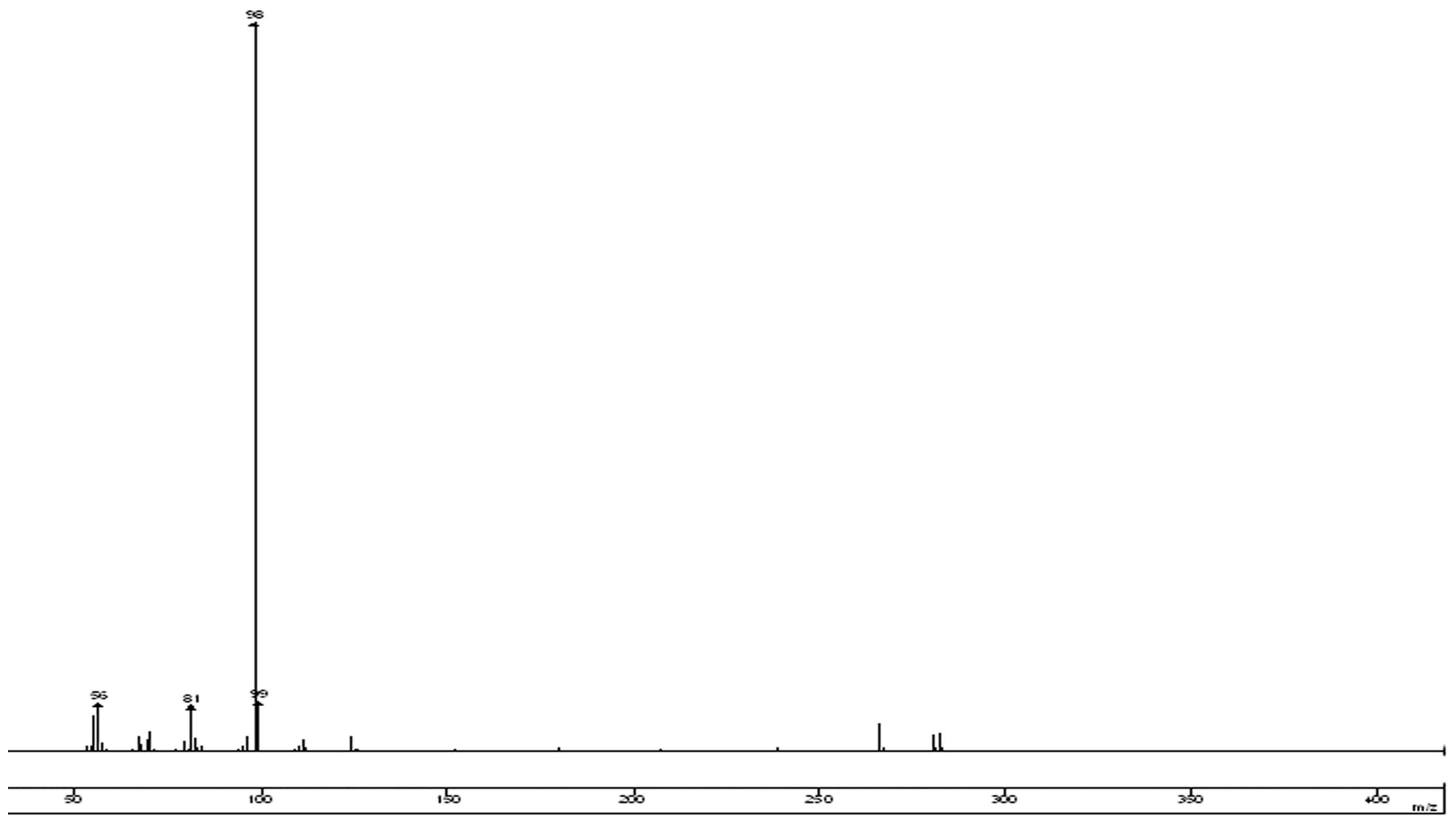

Figure S12. Mass spectrum of trans-2-methyl-6-tridecylpiperidine 


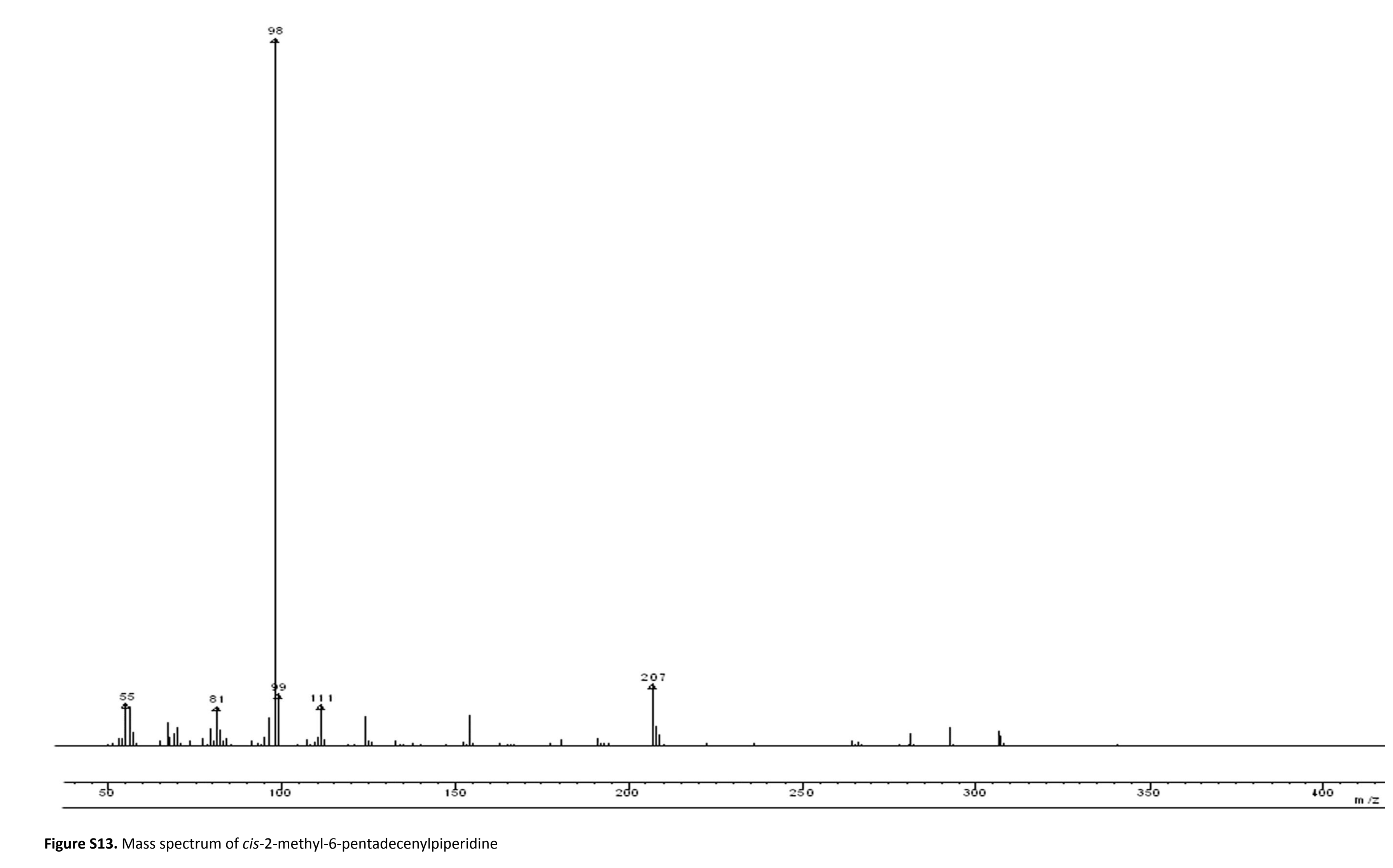




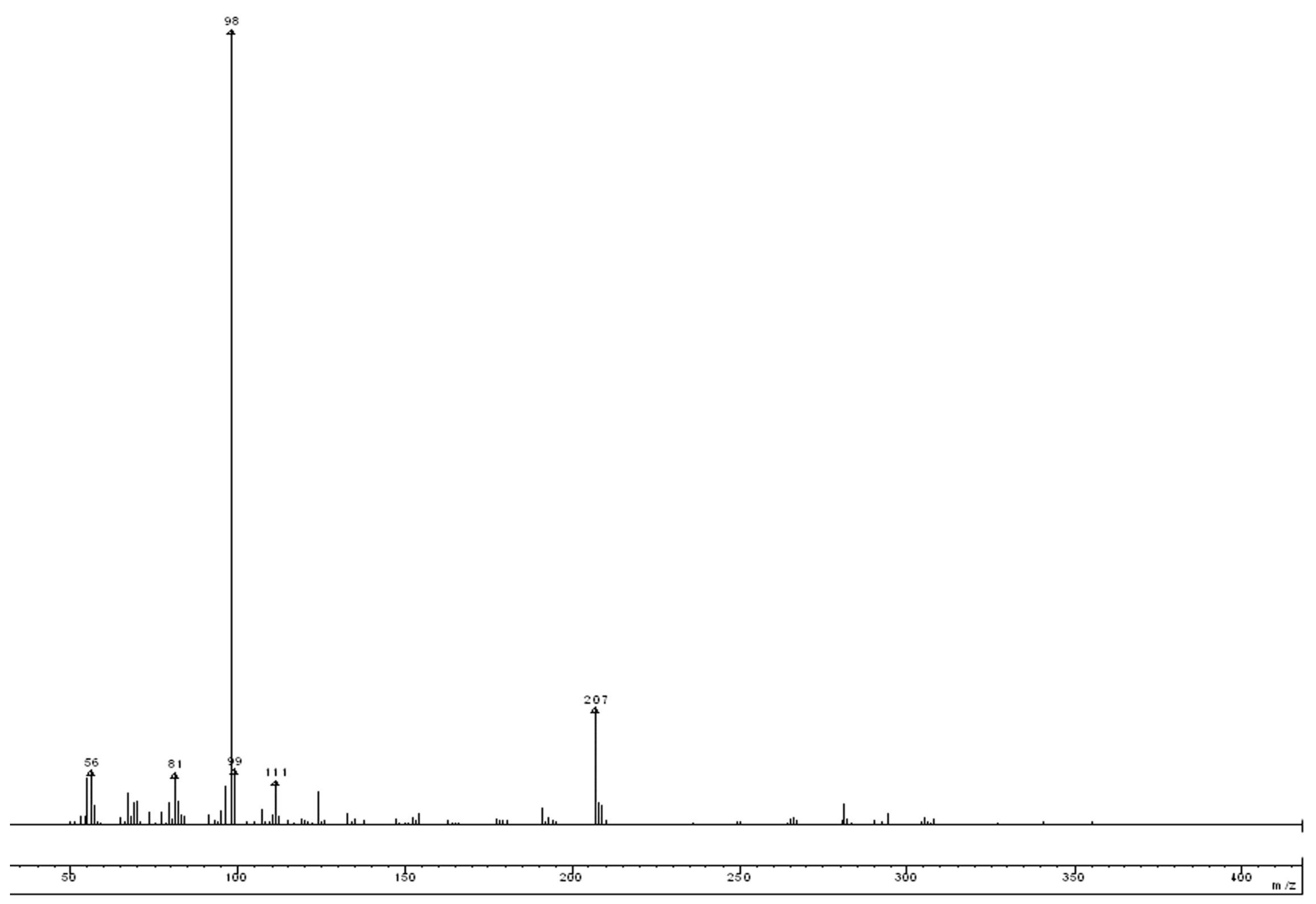

Figure S14. Mass spectrum of cis-2-methyl-6-pentadecylpiperidine 


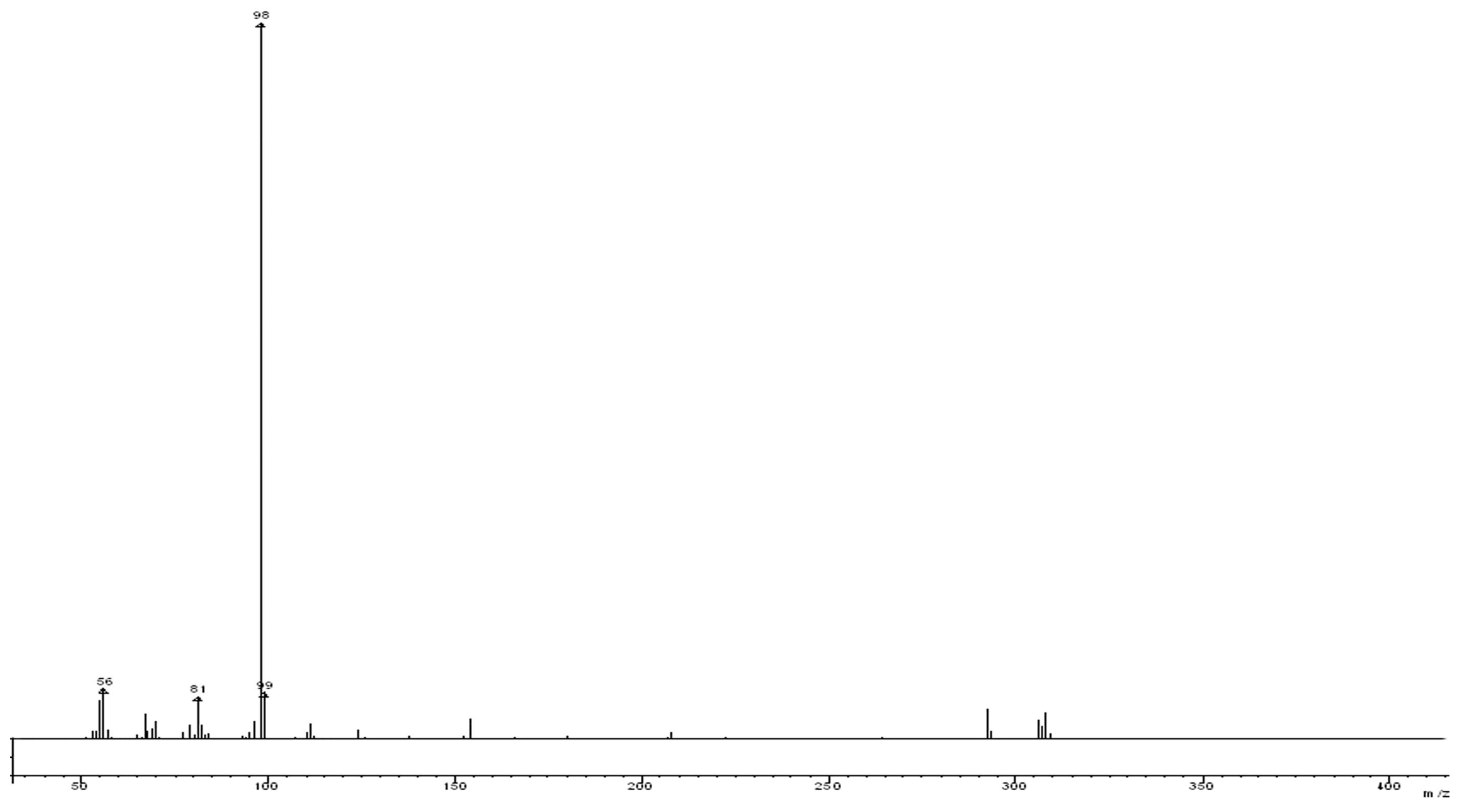

Figure S15. Mass spectrum of trans-2-methyl-6-pentadecenylpiperidine 


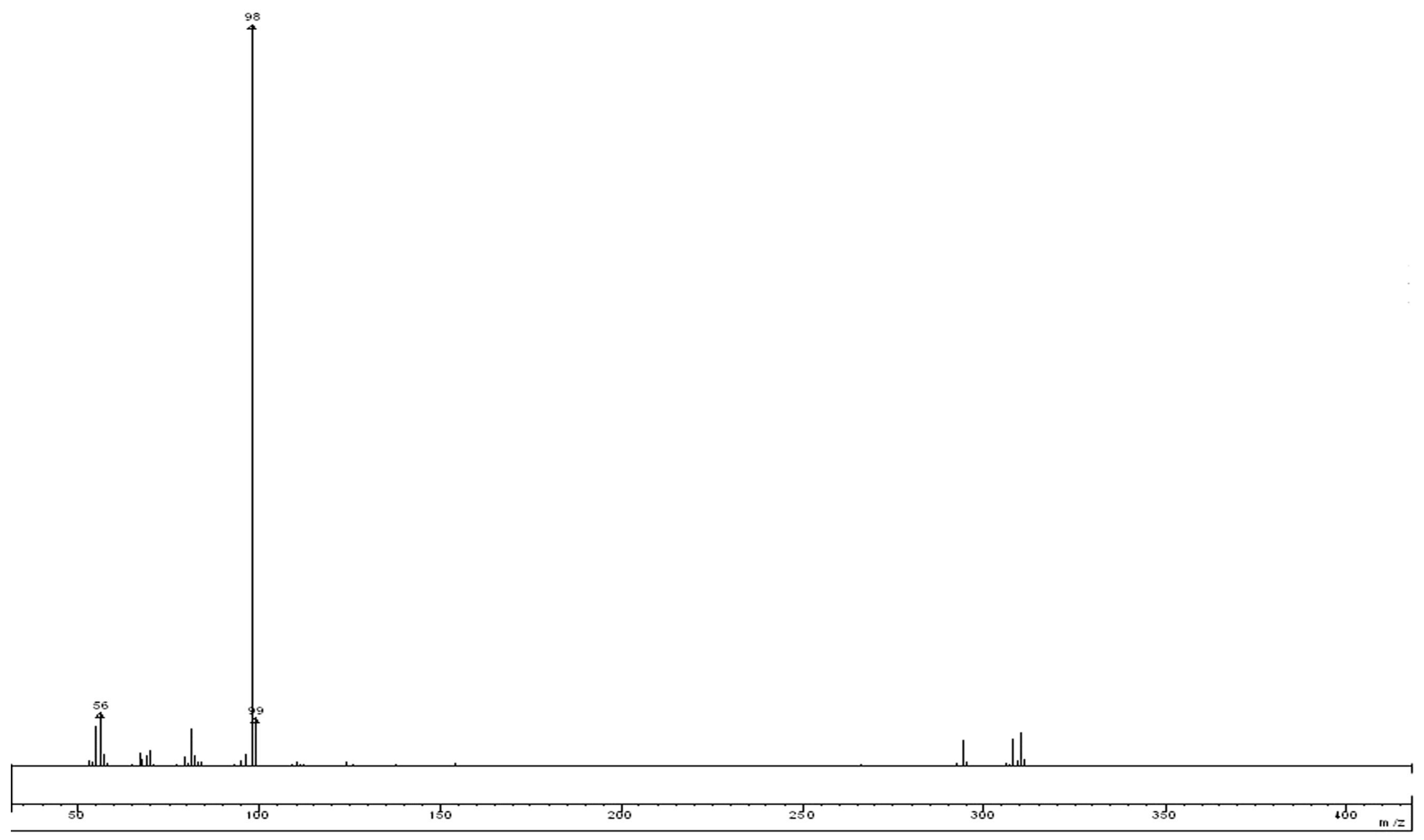

Figure S16. Mass spectrum of trans-2-methyl-6-pentadecylpiperidine 